\title{
Composition of the cell wall of Chlorella fusca
}

\author{
Eckhard Loos and Doris Meindl \\ Institut für Botanik der Universität, Universitätsstrasse 31, D-8400 Regensburg, Federal Republic of Germany
}

\begin{abstract}
Isolated cell walls of mature Chlorella fusca consisted of about $80 \%$ carbohydrate, $7 \%$ protein, and 13\% unidentified material. Mannose and glucose were present in a ratio of about $2.7: 1$ and accounted for most of the carbohydrate. Minor components were glucuronic acid, rhamnose, and traces of other sugars; galactose was absent. After treatment with $2 \mathrm{M}$ trifluoroacetic acid or with $80 \%$ acetic acid $/ \mathrm{HNO}_{3}(10 / 1, \mathrm{v} / \mathrm{v})$, a residue with a mannose/glucose ratio of $0.3: 1$ was obtained, probably representing a structural polysaccharide. An X-ray diffraction diagram of the walls showed one diffuse reflection at $0.44 \mathrm{~nm}$ and no reflections characteristic of cellulose. Walls from young cells contained about $51 \%$ carbohydrate, $12 \%$ protein, and $37 \%$ unidentified material. Mannose and glucose were also the main sugars; their absolute amounts per wall increased 6-7 fold during cell growth. Walls isolated with omission of a dodecylsulphate/mercaptoethanol/urea extraction step had a higher protein content and, with young walls, a significantly higher glucose and fucose content. These data and other published cell wall analyses show a wide variability in cell wall composition of the members of the genus Chlorella.
\end{abstract}

Key words: Cell wall (composition) - Chlorella.

\section{Introduction}

There are quite different reports in the literature on the composition of the cell walls of Chlorella (Northcote et al. 1958; Becker and Shefner 1964;

Abbreviations: $\mathrm{GLC}=$ gas liquid chromatography; TFA $=$ trifluoroacetic acid
Takeda and Hirokawa 1978). The aim of this work was to investigate the cell wall of Chlorella fusca, an alga used frequently in physiological and biochemical work. The walls from cells of different developmental stages were analyzed to learn to which extent the cell wall composition varies during the life cycle of Chlorella.

\section{Materials and methods}

Chlorella fusca Shihira et Kraus strain 211-8b was obtained from Sammlung für Algenkulturen, Göttingen, FRG. The algae were grown at $28^{\circ} \mathrm{C}$ in $1-1$ glass tubes $(6.5 \mathrm{~cm}$ diameter $)$ in the medium described by Kuhl (1962), which was bubbled with a $2 \% \mathrm{CO}_{2}$-air mixture. The culture was diluted daily to a density of $1-2 \cdot 10^{6}$ cells $\mathrm{ml}^{-1}$ at the beginning of a cycle of $14 \mathrm{~h}$ light $/ 12 \mathrm{~h}$ dark. The light $(6,000 \mathrm{~lx})$ was from fluorescent tubes. Release of autospores - usually eight from one mother cell - commenced $20 \mathrm{~h}$ after the onset of the light period and was completed within about $2 \mathrm{~h}$.

For preparing cell walls the algae were centrifuged, washed, and resuspended in water and passed 2 to 3 times through a French press; the breakage was $99.7 \%$ or better. The homogenate was centrifuged at $1,000 \mathrm{~g}$ for $10 \mathrm{~min}$, the pellet was washed twice with water and extracted at room temperature under stirring with methanol, chloroform/methanol $(1 / 2, \mathrm{v} / \mathrm{v})$, and methanol staying in each solvent for a $30-\min$ period. The residue was washed twice with water and incubated at $30^{\circ} \mathrm{C}$ in a mixture containing $0.02 \mathrm{M}$ potassium phosphate buffer (pH 6.2), $0.02 \% \mathrm{NaN}_{3}, 1 \mathrm{mM} \mathrm{CaCl}$, and 50 units/ml porcine $\alpha$-amylase (Sigma, St. Louis, Mo.). Depending on the starch content after 0.5 to $2 \mathrm{~h}$ the starch grains were dissolved as judged from microscopic examination and from tests for carbohydrate in the soluble fraction. The residue was washed twice with $\mathrm{H}_{2} \mathrm{O}$; extracted for two minutes at $100^{\circ} \mathrm{C}$ in a solution containing $8 \mathrm{M}$ urea, $2 \%$ sodiumdodecylsulphate, and $5 \%$ mercaptoethanol; washed several times with $\mathrm{H}_{2} \mathrm{O}$ and was freeze-dried. The cell wall preparation obtained in this way was white with a slightly yellow hue. It still contained about $8 \%$ water which was lost by heating for two hours at $105^{\circ} \mathrm{C}$. All analyses carried out with the freeze-dried material were corrected for the residual water.

Total carbohydrate content was measured with the phenolesulphuric acid method (Dubois et al. 1956). Uronic acids were determined with a carbazole reagent (Galambos 1967) and 
protein according to Lowry et al. (1951), the standards being glucuronic acid and bovine serum albumin, respectively. For complete analysis of neutral sugars, a hydrolysis with sulphuric acid was carried out as described by Saeman et al. (1945). Hydrolysis in $2 \mathrm{M}$ trifluoroacetic acid (TFA) was carried out for $6 \mathrm{~h}$ at $100^{\circ} \mathrm{C}$ (Mankarios et al. 1979). Neutral sugars were derivatized to yield the respective alditol acetates and separated by gas liquid chromatography with $3 \%$ SP-2340 on Supelcoport $100 / 120$ (Supelco) as the column material. Inositol was used as the internal standard. Thin-layer chromatographic separation of sugars was achieved on cellulose sheets in system A according to Wolfrom et al. (1965); uronic acids were separated on silica gel in the solvent system 18 from Ghebregzabher et al. (1976). Staining was done with a diphenylamine reagent. To hydrolyze the protein component the cell walls were incubated for $18 \mathrm{~h}$ at $105^{\circ} \mathrm{C}$ in $6 \mathrm{M} \mathrm{HCl}$ containing $0.2 \%$ mercaptoethanol and a few crystals of phenole. Qualitative analyses of amino acids were obtained by two-dimensional thin-layer chromatography with chloroform $/$ methanol $/ 17 \%$ ammonia $=40 / 40 / 20$ v) (first dimension) and phenole $/$ water $=75 / 25(\mathrm{w} / \mathrm{w})$; spots were developed with a ninhydrin reagent. Quantitative analyses were carried out with a Biotronic amino acid analyzer with a fluorometric detection system. Norleucine was added in these experiments as the internal standard.

\section{Results}

Cell walls from mature algae. Analyses were carried out with cell walls obtained from algae harvested $16 \mathrm{~h}$ after inoculation. At this stage the algae had grown to full size (diameter about $9.5 \mu \mathrm{m}$ ) and the cell contents had a granular appearance.

Table 1, first column, shows that $80 \%$ of the cell wall were carbohydrate including uronic acids; less than $10 \%$ were made up of protein and $13 \%$ were of an unknown nature. A determination with another cell wall preparation gave essentially the same results.

The ash content was found to be very low. From $141.5 \mathrm{mg}$ cell walls of different developmental stages $0.3 \mathrm{mg}$ ash were obtained, representing only $0.2 \%$.

The distribution of neutral sugars after hydrolysis of the cell walls in sulphuric acid was determined by gas liquid chromatography (GLC) and is shown in Table 2, column 1. The dominant sugar was mannose followed by glucose and very little rhamnose; these sugars could also be detected by thin-layer chromatography. Xylose, fucose, and arabinose were present in trace amounts only; galactose, however, was absent in all cases. The highest and lowest figures for mannose were $79.0 \%$ and $60.6 \%$ in a series of six different cell wall preparations. The sum of the neutral sugars amounted to about $70 \%$ of the cell walls' dry weight and therefore represented the bulk of the carbohydrate (cf. Table 1).

Hydrolysis in TFA was employed to separate $\alpha$-cellulosic material (TFA-resistant) from a solu-
Table 1. Composition of the cell wall of Chlorella fusca at different developmental stages. The carbohydrate content was calculated with an extinction coefficient for a mannose-glucose mixture of the percentual composition as found in the cell wall hydrolysates. The values for uronic acids were multiplied by 0.63 to correct for color formation due to the neutral sugars

\begin{tabular}{llcc}
\hline & \multicolumn{3}{l}{ h after inoculation } \\
\cline { 2 - 4 } & \multicolumn{1}{l}{16} & 24 & $24^{\mathrm{a}}$ \\
\cline { 2 - 4 } & $\%$ of dry weight \\
\hline Carbohydrate & 76.5 & 49.7 & 32.1 \\
Uronic acids & 3.4 & 2.3 & 1.3 \\
Protein & 7.2 & 11.7 & 36.2 \\
Unknown & 12.9 & 36.3 & 30.4 \\
\hline a Cell walls not treated with dodecylsulphate/mercaptoethanol/ \\
$\quad$ urea
\end{tabular}

Table 2. Distribution of neutral sugars in cell walls of Chlorella fusca at different developmental stages

\begin{tabular}{|c|c|c|c|}
\hline & \multicolumn{3}{|c|}{$\mathrm{h}$ after inoculation } \\
\hline & 16 & 24 & $24^{a}$ \\
\hline & \multicolumn{3}{|c|}{$\%$ (by weight) of sum } \\
\hline Mannose & 71.7 & 65.7 & 45.2 \\
\hline Glucose & 26.4 & 30.4 & 38.7 \\
\hline Rhamnose & 1.3 & 1.9 & 1.0 \\
\hline Fucose & 0.2 & 0.4 & 12.4 \\
\hline Others & 0.4 & 1.6 & 2.7 \\
\hline
\end{tabular}

a Cell walls not treated with dodecylsulphate/mercaptoethanol/ urea

Table 3. Distribution of neutral sugars in different cell wall fractions of Chlorella fusca. Man = mannose; Gluc = glucose; $\mathrm{TFA}=$ trifluoroacetic acid

\begin{tabular}{lllll}
\hline Fraction & $\begin{array}{l}\text { \% of the } \\
\text { walls' dry }\end{array}$ & Man & Gluc & Others \\
\cline { 4 - 5 } & weight & \% (by weight) of sum & \\
\hline TFA-hydrolyzable & 42.5 & 86.3 & 8.3 & 5.4 \\
$\begin{array}{l}\text { TFA-resistant } \\
\begin{array}{l}\text { Resistant to } \\
\text { extraction }\end{array}\end{array}$ & 23.3 & 20.7 & 76.4 & 2.9 \\
\hline
\end{tabular}

a Extraction was carried out after Updegraff (1969) for $30 \mathrm{~min}$ at $100^{\circ} \mathrm{C}$ in a mixture of $80 \%$ acetic acid $/ \mathrm{HNO}_{3}=10 / 1(\mathrm{v} / \mathrm{v})$

ble fraction (Mankarios et al. 1979). The latter (almost half of the cell walls' dry weight) was composed largely of mannose (Table 3). Thin-layer chromatography revealed, besides mannose and glucose, an unknown faint spot above rhamnose and a spot at the site of uronic acids. Upon elution and rechromatography in a different solvent system, this region yielded only glucuronic acid. 

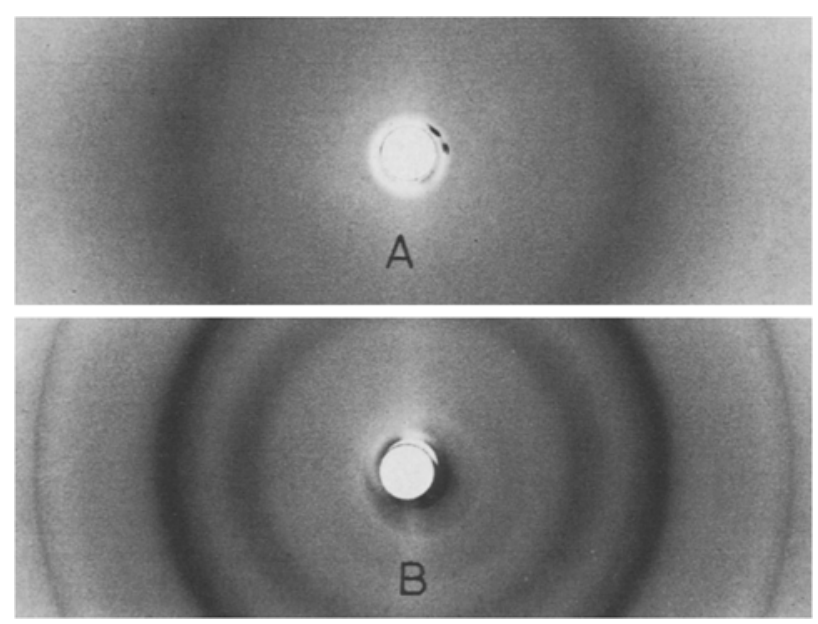

Fig. 1. X-ray diffraction diagrams obtained with the DebyeScherrer method of cell walls of Chlorella fusca (A) and of $\alpha$-cellulose (B). Samples were in $0.7 \mathrm{~mm}$ capillary tubes, radiation was the $\mathrm{Cu} \mathrm{K} \alpha$ line. Treatment of $\alpha$-cellulose with dodecylsulphate/mercaptoethanol/urea as in the cell wall isolation procedure had no effect on the X-ray diffraction diagram

The TFA-insoluble fraction was subjected to hydrolysis in $\mathrm{H}_{2} \mathrm{SO}_{4}$ and was found to consist of about three-quarters glucose and one-fifth mannose (Table 3). In another approach to demonstrate an $\alpha$-cellulosic component, the cell walls were extracted according to Updegraff (1969). The residue showed upon hydrolysis in $\mathrm{H}_{2} \mathrm{SO}_{4}$ essentially the same sugar distribution (Table 3) and is thus obviously not pure cellulose.

To see whether a structural polysaccharide similar to cellulose was present in the cell walls, an X-ray diffraction study was undertaken. Only one diffuse reflection could be detected corresponding to a mean interplanar spacing of $0,44 \mathrm{~nm}$ (Fig. 1A). A picture from authentic $\alpha$-cellulose (Fig. 1B) revealed reflections at $0.25,0.39,0.44$, and around $0.55 \mathrm{~nm}$. It is concluded that the walls of Chlorella fusca contain a weakly crystalline component which is different from $\alpha$-cellulose.

Hydrolyses of the cell walls yielded the following amino acids in quantitative analyses: Ala, Thr, Gly, Val, Asp, Ser, Leu, Ile, Lys, Glu, Phe, Arg, Tyr, Met, His. Alanine, threonine, and glycine were the most prominent ones; histidine and an amino sugar, most probably glucosamine, were present only in trace amounts. From the sum of the amino acids a protein content of $6 \%$ was calculated. This is in fair agreement with the value obtained by the Lowry method (cf. Table 1). From the quantitative determinations no data were available for proline and hydroxyproline, since they escape the detection system employed. Qualitative analyses using thin-layer chromatography did not reveal these two amino acids. However, all the amino acids listed above except histidine were also found with this method; amino sugars could not be detected. Two unknown ninhydrin-positive spots were encountered, one migrating like Lys in the first dimension and like Glu in the second one, the other migrating like Arg and Ala.

Cell walls from algae of different developmental stages. The cell wall composition of algae harvested 8 and $24 \mathrm{~h}$ after inoculation was also studied. The former cells were slightly elliptical with axes of about 8.9 and $7.6 \mu \mathrm{m}$, whereas in the latter case the freshly hatched cells were of a clear oblong shape with axes of about 6.0 and $3.6 \mu \mathrm{m}$. The walls from the 8 -h stage were in their composition similar to those from the 16-h stage (data not shown); the walls from young cells, however, contained relatively less carbohydrate, more protein, and a considerable fraction of unidentified material (Table 1). The pattern of neutral sugars was essentially unchanged (Table 2).

To determine the absolute amounts of mannose and glucose on a cell number base the walls of a known number of cells were prepared quantitatively, hydrolyzed, and analyzed. Although the data were scattering, it became clear that the amounts of mannose and glucose increased 6- to 7-fold during cell growth, reaching 1.7 and $0.6 \mathrm{pg} /$ cell wall, respectively. A several-fold increase was also noted for the dry weight for which orienting experiments yielded $0.49,2.26$, and $3.70 \mathrm{pg} /$ wall for the 24-, 8-, and 16-h stages. These values represented around $4 \%$ of the cells' dry weight.

Cell walls isolated by a milder procedure. The results reported so far were obtained with cell walls extracted with dodecylsulphate/mercaptoethanol/ urea. Since during this procedure some wall components may have been lost, analyses were carried out with walls not treated in this way.

The protein content of this material from young cells (and also older cells) was relatively high and the carbohydrate content somewhat lower (Table 1, column 3). The pattern of neutral sugars was changed significantly showing a higher percentage of glucose and fucose (Table 2, column 3); this change, however, was not seen in the older stages (data not shown). Obviously, the extraction with dodecylsulphate/mercaptoethanol/urea removed from the young cell walls protein, glucose, and fucose, eventually belonging to a glycoprotein. It remains an open question, however, to which extent this dissolved material is a true cell wall component or a contamination, e.g., from the cytoplasm. 


\section{Discussion}

Most of the cell wall of Chlorella fusca consists of a galactose-free carbohydrate with mannose and glucose as its main constituents. These were the main sugars in different developmental stages and also with different cell wall isolation procedures. They represent, therefore, a constant property of the wall of $C$. fusca. This alga - previously known as C. pyrenoidosa Chick - is distinct from two strains of $C$. pyrenoidosa containing in the cell wall chiefly galactose and glucose (Northcote et al. 1958 ) or, in addition, rhamnose (Becker and Shefner 1964). However, cell walls rich in mannose have been reported for the chlorococcal algae Hydrodictyon (Northcote et al. 1960) and Pediastrum (Parker 1964). In C. fusca the structural polysaccharide was composed largely of glucose (Table 3 ). This is similar to C. pyrenoidosa (Northcote et al. 1958), but is different from C. ellipsoidea, having $>50 \%$ glucosamine in the fibrillar material (Takeda and Hirokawa 1978). It would be of interest to see whether this diversity for the cell wall's main sugars would turn out to be even wider upon examination of other Chlorella species.

$X$-ray diffraction diagrams of cell walls of $C$. fusca revealed only weakly crystalline material, as is the case with several other algae (cf. Kreger 1962). The observed reflection was different from cellulose for which evidence from X-ray data seems to exist in the order Chlorococcales only for Oocystis (Robinson and White 1972); it also differed from $\beta$-1,4-mannan (main reflection $0.56 \mathrm{~nm}$ ) which occurs as structural polysaccharide in cell walls of members of the Caulerpales and Dasycladales (Iriki and Miwa 1960; Frei and Preston 1961).

In the amino acid analyses of the cell walls hydroxyproline could not be detected. Obviously, C. fusca does not contain a hydroxyproline-rich glycoprotein in its wall, in contrast to C. vulgaris and higher plants (Lamport and Miller 1971). This is further supported by the fact that arabinose an integral sugar of such a glycoprotein - was present only in trace amounts or sometimes even missing. A variability in the occurrence of hydroxyproline is also indicated by the data of Punnet and Derrenbacker (1966), who were able to detect hydroxyproline in the wall of only one from three examined species of Chlorella.

Thanks are due to Rudi Dirscherl and Ina Hecht for experimental help and to Dr. F. Wieland and R. Heitzer for the quantitative amino acid analyses. Dr. M. Zabel kindly took the X-ray diffraction diagrams. This work was supported by the Deutsche Forschungsgemeinschaft.

\section{References}

Becker, M.J., Shefner, A.M. (1964) Thin-layer and paper chromatographic analyses of the carbohydrates in the cell wall of Chlorella pyrenoidosa 7-11-05. Nature (London) 202, 803-804

Dubois, M., Gilles, K.A., Hamilton, J.K., Rebers, P.A., Smith, F. (1956) Colorimetric method for determination of sugars and related substances. Anal. Chem. 28, 350-356

Frei, E., Preston, R.D. (1961) Variants in the structural polysaccharides of algal cell walls. Nature (London) 192, 939-943

Galambos, J.T. (1967) The reaction of carbazole with carbohydrates I. Effect of borate and sulfamate on the carbazole color of sugars. Anal. Biochem. 19, 119-132

Ghebregzabher, M., Rufini, S., Monaldi, B., Lato, M. (1976) Thin-layer chromatography of carbohydrates. J. Chromatogr. 127, 133-162

Iriki, Y., Miwa, T. (1960) Chemical nature of the cell wall of the green algae, Codium, Acetabularia and Halicoryne. Nature (London) 185, 178-179

Kreger, D.R. (1962) Cell walls. In: Physiology and biochemistry of algae, pp. 315-335. Lewin, R.A., ed. Academic Press, New York London

Kuhl, A. (1962) Zur Physiologie der Speicherung kondensierter anorganischer Phosphate in Chlorella. In: Beiträge zur Physiologie und Morphologie der Algen, pp. 157-166, Deutsche Botanische Gesellschaft, ed. Fischer, Stuttgart

Lamport, D.T.A., Miller, D.H. (1971) Hydroxy-proline arabinosides in the plant kingdom. Plant Physiol. 48, 454-456

Lowry, O.H., Rosebrough, N.J., Farr, A.L., Randall, R.J. (1951) Protein measurement with the folin phenol reagent. J. Biol. Chem. 193, 265-275

Mankarios, A.T., Jones, C.F.G., Jarvis, M.C. (1979) Hydrolysis of plant polysaccharides and GLC analysis of their constitutent neutral sugars. Phytochemistry 18, 419-422

Northcote, D.H., Goulding, K.J., Horne, R.W. (1958) The chemical composition and structure of the cell wall of Chlorella pyrenoidosa. Biochem. J. 70, 391-397

Northcote, D.H., Goulding, K.J., Horne, R.W. (1960) The chemical composition and structure of the cell wall of $\mathrm{Hy}$ drodictyon africanum Yaman. Biochem. J. 77, 503-508

Parker, B.C. (1964) The structure and chemical composition of cell walls in three chlorophycean algae. Phycologia 4, 63-74

Punnet, D., Derrenbacker, E.C. (1966) The amino acid composition of algal cell walls. J. Gen. Microbiol. 44, 105-114

Robinson, D.G., White, R.K. (1972) The fine structure of $\mathrm{Oo}_{0}$ cystis apiculata W. West with particular reference to the wall. Br. Phycol. J. 7, 109-118

Saeman, J.F., Buhl, J.L., Harris, E.F. (1945) Quantitative saccharification of wood and cellulose. Ind. Eng. Chem., Anal. Ed. 17, 35-37

Takeda, H., Hirokawa, T. (1978) Studies on the cell wall of Chlorella. I. Quantitative changes in cell wall polysaccharides during the cell cycle of Chlorella ellipsoidea. Plant Cell Physiol. 19, 591-598

Updegraff, D.M. (1969) Semimicro determination of cellulose in biological materials. Anal. Biochem. 32, 420-424

Wolfrom, M.L., Patin, D.L., de Lederkremer, R.M. (1965) Thin-layer chromatography on microcrystalline cellulose. J. Chromatogr. 17, 488-494

Received 4 June; accepted 3 August 1982 